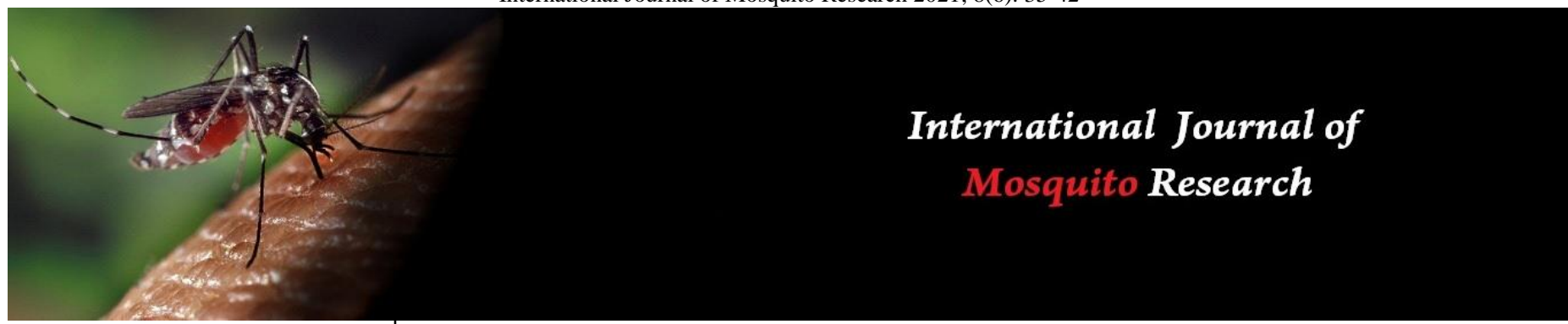

ISSN: 2348-5906

CODEN: IJMRK2

IJMR 2021; 8(6): 35-42

(C) 2021 IJMR

www.dipterajournal.com

Received: 19-09-2021

Accepted: 21-10-2021

Kilimas Rajan

Department of Botany,

St. Joseph's College

(Autonomous), Tiruchirappalli,

Tamil Nadu, India

Ananthakumar Archana

Department of Botany,

St. Joseph's College

(Autonomous), Tiruchirappalli,

Tamil Nadu, India

Sathiyanarayanan Anusuya

Department of Botany,

St. Joseph's College

(Autonomous), Tiruchirappalli,

Tamil Nadu, India
Corresponding Author:

Kilimas Rajan

Department of Botany,

St. Joseph's College

(Autonomous), Tiruchirappalli,

Tamil Nadu, India

\section{Larvicidal potential of certain plant extracts of the family Lamiaceae against Anopheles subpictus (Diptera: Culicidae)}

\author{
Kilimas Rajan, Ananthakumar Archana and Sathiyanarayanan Anusuya
}

DOI: $\underline{\text { https://doi.org/10.22271/23487941.2021.v8.16a.570 }}$

Abstract

The present study was undertaken to check and compare the virtue of plant extracts in relation to larvicidal activities against Anopheles subpictus. The lethality and toxicity of methanolic and aqueous extracts of Ocimum sanctum, Ocimum basilicum, Leucas aspera and Coleus amboinicus to early $4^{\text {th }}$ instar larvae of A. subpictus were determined in the laboratory. All plant extracts of Lamiaceae showed moderate effect against the larvae of A. subpictus after 24 hours exposure as evidenced by low lethal concentration and lethal time and the lethality varied in larvae and the crude plant extracts. The mortality rate was recorded after 24 hours of exposure and $\mathrm{LC}_{50}$ was determined. Larval mortality between $80 \%$ and $92 \%$ was observed in methanolic extract and $60-85 \%$ in aqueous extracts of selected plant species. The highest larvicidal activity against $A$. subpictus was obtained with methanol extract of $O$. sanctum. The present findings have paramount implications in the practical control of mosquito larvae and adults in the aquatic ecosystem as the medicinal plants studied are routinely accessible in enormous quantities. These plant extracts are easy to prepare, inexpensive, and safe for mosquito control which might be used directly as larvicidal agents in small dimension aquatic habitats or breeding sites around human dwellings.

Keywords: A. subpictus, larvicidal, plant extract, lethal, mosquito control, lamiaceae

\section{Introduction}

The natural history of malaria involves cyclical infection of humans and female Anopheles mosquitoes. It is the only known carrier of malaria, also transmits filariasis, encephalitis and arbovirus infections. As vectors, Anopheles mosquitoes have affected the lives of more human than any other insect and engender a great impact on human genome evolution ${ }^{[1]}$. Vector control targeting the larval stages of mosquitoes was applied successfully against many species of Anopheles (Diptera: Culicidae) in several countries until the mid-20th Century ${ }^{[2]}$.

The regulator of larval or pupal periods plays a major role in mosquito population management which includes environmental control, biotic control and insecticidal control [3]. However spraying of insecticides containing organophosphates, pyrethrum and bacterium byproducts can result in insecticide resistance, environmental pollution and pose a serious threat to ecosystem ${ }^{[4]}$. The concerns about insecticide resistance and environmental impacts have stimulated renewed interest in larval control involving temporary or permanent removal of anopheline larval habitats, as well as larviciding with biological agents or plant based products which are ecofriendly nature.

Solicitation of a mosquito fish, Gambusia affinis against this vector, has shown capable efficiency in decreasing the mosquito population and malaria cases in India ${ }^{[5]}$. Biological compounds tend to be more expensive than chemical controls but they affect fewer non-target organisms ${ }^{[6]}$. In recent years, plant derived products has been revived as they contain a rich source of bioactive phytochemicals that are safe and biodegradable into non-toxic by-products, which could be screened for insecticidal activities. Many plant extracts have been tested against various species of mosquitoes, focusing on larvicidal action ${ }^{[7]}$. For instance, leaf extracts of Eclipta prostrata and Andrographis paniculata were reported to be effective against fourth instar larvae of $A$. subpictus ${ }^{[8]}$. 
Essential oil from Ocimum basilicum (L.) was evaluated for larvicidal activity against Culex tritaeniorhynchus, Aedes albopictus and Anopheles subpictus ${ }^{[9]}$. Extract of Ligusticum sinense, essential oils of citronella, pine, Dalbergia sissoo, peppermint and Rhizophora mucronata are reported to exert high activity against different species of Anopheles ${ }^{[10]}$. In this context, a comparative study was undertaken to evaluate the larvicidal activity of Ocimum sanctum L., Ocimum basilicum L., Leucas aspera (Willd.) Link and Coleus amboinicus Lour of Lamiaceae family against Anopheles subpictus.

\section{Materials and Methods}

\subsection{Biological material}

Leaves of Ocimum sactum, Ocimum basilicum, Leucas aspera and Coleus amboinicus were collected in the month of February, 2021 at Thiruverumbur town of Tiruchirappalli city (Latitude $10.784770 \quad \mathrm{~N}$, Longitude 78.784050 E). The collected plants species were identified and authenticated at St. Joseph's College, Tiruchirappalli (Fig. 1). Leaves were shade dried at room temperature for 7 days and ground to fine powder using a mechanical blender. Anopheles subpictus eggs were collected from the sewage water at St. Joseph's College, Tiruchirappalli. The eggs were placed in distilled water to hatch. The emerging larvae were reared and tested at $28 \pm 2{ }^{\circ} \mathrm{C}$ temperature, $\geq 45 \pm 10 \%$ relative humidity, and a 12:12 (light: dark) photoperiod and were fed tropical fish flakes.
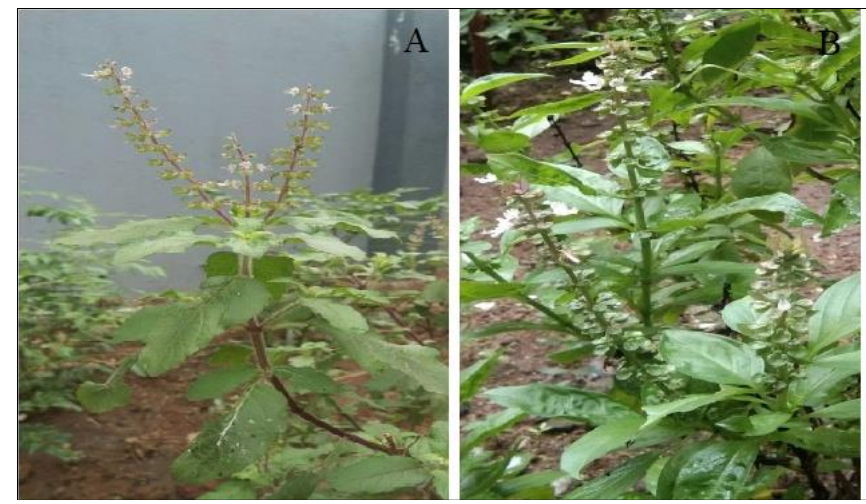

Fig 1: Image of A. Ocimum sanctum L. B. Ocimum basilicum L. C.

\subsection{Preparation of plant extracts}

For methanolic extract, $250 \mathrm{~g}$ of finely powered leaves were extracted with methanol in a Soxhlet apparatus (boiling point range $50-80^{\circ} \mathrm{C}$ ) for 8 hours. For aqueous extracts, $250 \mathrm{~g}$ of leaf powder was extracted with water in a boiling water bath $\left(60^{\circ} \mathrm{C}\right)$ for 4 hours and filtered through muslin cloth. Both the extracts were concentrated under reduced pressure (22-26 $\mathrm{mm} \mathrm{Hg}$ ) at $45{ }^{\circ} \mathrm{C}$. The obtained residue was stored at room temperature.

\subsection{Phytochemical screening}

The phytochemical screening test was performed as described by Trease and Evans ${ }^{[11]}$ and Sofowora ${ }^{[12]}$.

\subsection{Fourier-transform infrared spectroscopy (FTIR) Analysis}

FTIR identifies the presence of organic and inorganic compounds in the sample. FTIR spectrum of aqueous and methanolic extracts of $O$. sanctum, $O$. basilicum, $L$. aspera, $C$. amboinicus was recorded in the range of $4000-400 \mathrm{~cm}-1$ using FTIR spectrophotometer (Spectrum RX I, PERKIN ELMER).

\subsection{Larvicidal bioassay}

The larvicidal activity of the plant extracts was evaluated according to the World Health Organization guidelines for laboratory ${ }^{[13]}$. The biological activity of the extracts of collected plant leaves used in the laboratory was found in late L3 and/ or early L4 larval stages of populations of Anopheles subpictus to obtain the lethal concentrations $\left(\mathrm{LC}_{50}\right)$ value. The methanolic and aqueous crude extracts were evaluated at the concentrations of 200, 400, 600, 800 and $1000 \mathrm{mg} / \mathrm{L}$. Batches of 20 healthy third/fourth instars of larvae were transferred to
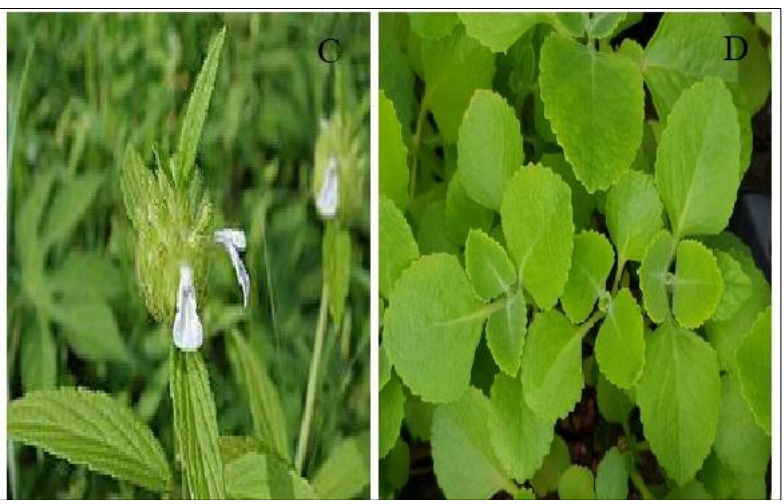

C. Leucas aspera (Willd) link D. Coleus amboinicus Lour.

petri plates containing $100 \mathrm{ml}$ of distilled water. Then various concentrations of crude extracts were added and the experiments were replicated thrice along with control (water served as control). All the plates were left undisturbed for 24 hours including control. Effect of sub lethal (lethal concentrations of cumulative effect) plant extracts were established through $\mathrm{LC}_{50}$ value determined with the test larvicide after 24 hours of exposure to plant extracts. Daily observation was made with verification of larval stages, behavior changes, possible mortality of the larvae and the temperature. The experiment was conducted until the last pupa or adult died or until the last adult completely emerged. The number of lifeless larvae (no appendage movement or leaping reaction in water) was counted after 24 hours of revelation and the percentage mortality was calculated from the average of three replicates. The mortality rate was calculated by this formula: Percentage of mortality=Total no. of dead larvae/Total no. of larvae introduced x 100 using the scale range

- Mortality in variation of $98-100 \%$ indicates defenselessness.

- Mortality in variation of $80-97 \%$ is indicative of the survival of resistance and further study is needed.

- Mortality fewer than $80 \%$ specifies resistance.

\subsection{Statistics analysis}

Larval mortality counts were in tune for the mortality in control, if any, by using Abbott's formula ${ }^{[14]}$ to give an estimation of the plant extracts reasonable mortality. The rectified mortality data were subjected to regression analysis of $\%$ table of Probit mortality on log dosage ${ }^{[15]}$. The significant variance in $\mathrm{LC}_{50}$ is established on the nonoverlapping of $95 \%$ Fiducial limits and P-values $<0.05$ were 
considered to be statistically important ${ }^{[15]}$.

\section{Results and Discussion}

The aim of this study was to establish the larvicidal activity of Ocimum sanctum, Ocimum basilicum, Leucas aspera and Coleus amboinicus against Anopheles and identify the compounds responsible for the observed activity. This work adds to the current efforts worldwide to discover new mosquito control agents. Plant bioactive chemicals are generally considered as nontoxic, easily available at affordable prices, biodegradable and show broad spectrum target-specific activities against different species of vector mosquitoes ${ }^{[16]}$.

\subsection{Phytochemical analysis}

Phytochemical screening of selected plants showed the presence of alkaloids, flavanoids, terpenoids, saponins and phenolics (Table 1). Among the selected plants, methanolic extract of Ocimum sanctum showed higher amount of terpenoids while the aqueous extract showed saponins (Table 2). Tanins and phenolic compounds were absent in Leucas aspera of both methanol and aqueous extracts.

Table 1: Phytochemical analysis of Aqueous extracts of $O$. sanctum, O. basilicum, L. aspera, C. amboinicus.

\begin{tabular}{|c|c|c|c|c|c|}
\hline S. No & Secondary metabolites & O. sanctum & O. basilicum & L. aspera & C. amboinicus \\
\hline 1. & Alkaloids & + & + & ++ & - \\
\hline 2. & Flavonoids & + & ++ & + & + \\
\hline 3. & Tannins & ++ & + & - & + \\
\hline 4. & Saponins & +++ & ++ & + & ++ \\
\hline 5. & Terpenoids & + & ++ & + & - \\
\hline 6. & Phenols & + & + & - & + \\
\hline
\end{tabular}

Table 2: Phytochemical analysis of methanolic extracts of $O$. sanctum, O. basilicum, L. aspera, C. amboinicus.

\begin{tabular}{|c|c|c|c|c|c|}
\hline S. No & Secondary metabolites & O. sanctum & O. basilicum & L. aspera & C. amboinicus \\
\hline 1. & Alkaloids & + & ++ & ++ & + \\
\hline 2. & Flavonoids & + & ++ & + & ++ \\
\hline 3. & Tannins & ++ & + & - & + \\
\hline 4. & Saponins & - & ++ & + & + \\
\hline 5. & Terpenoids & +++ & + & + & + \\
\hline 6. & Phenols & ++ & + & - & + \\
\hline
\end{tabular}

\subsection{FTIR analysis}

Depending on the infrared absorption frequency range 600$4000 \mathrm{~cm}^{-1}$, the specific molecular groups prevailing in the sample were determined through spectrum data obtained for aqueous and methanolic extracts of selected plants. In general, crude methanolic extracts showed more number of asymmetric bands than aqueous extracts of selected plants of Lamiaceae. All the samples of both the extracts showed characteristic absorption peaks in the range of $640 \mathrm{~cm}-1$ to $690 \mathrm{~cm}-1$ which accounts for the presence of aromatic compounds and peaks in the range of $3390 \mathrm{~cm}-1$ to $3452 \mathrm{~cm}-$ 1 indicates the presence of amines (Fig. 2). Essential oils containing biological active constituents are known to possess insecticidal and nematicidal activities ${ }^{[17,18]}$. Eugenol has been reported to be largely seen in Ocimum and responsible for the therapeutic potential ${ }^{[19]}$.

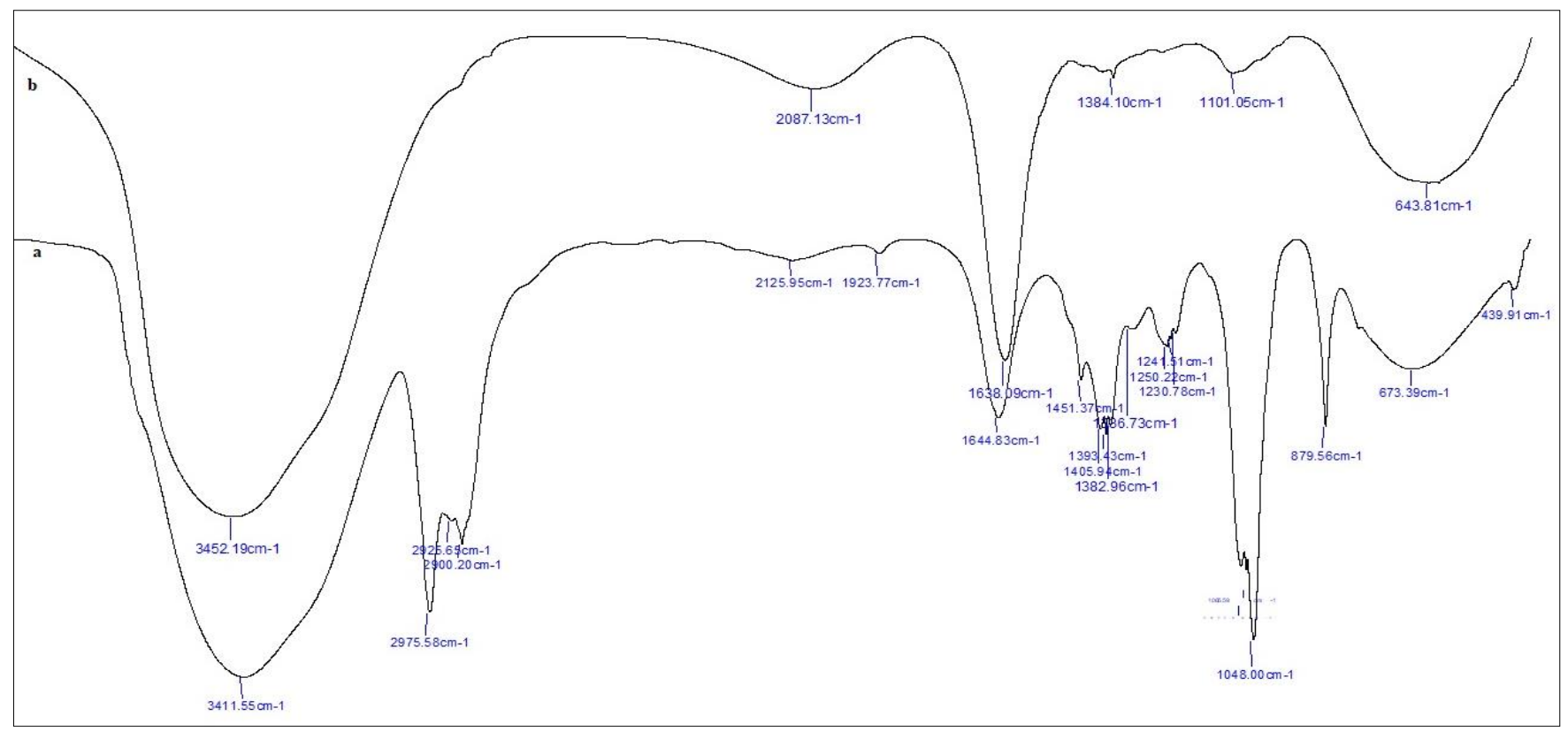

Fig 2: FTIR spectra of methanolic (a) and aqueous (b) extracts of Ocimum sanctum 
Bands around $1638 \mathrm{~cm}-1$ and 1384 in aqueous extracts of selected plants are believed to be arising from the $\mathrm{N}-\mathrm{O}$ asymmetric and symmetric stretching bands, respectively, of the aromatic $\mathrm{NO}_{2}$ group. Aqueous extracts of selected plants showed a characteristic peak at $1634 \mathrm{~cm}-1$ attributing to amides which are not observed in methanolic extracts (Fig. 3).

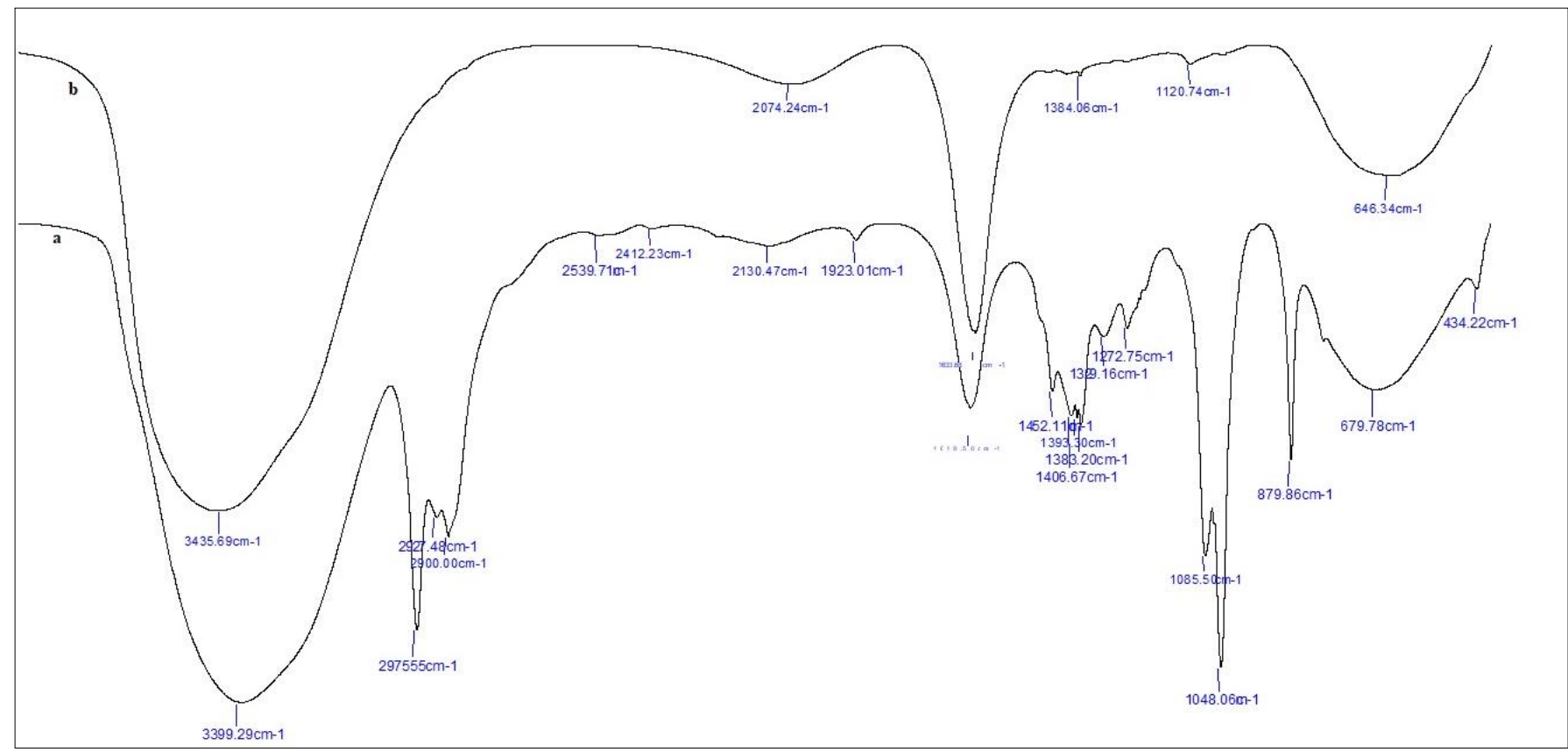

Fig 3: FTIR spectra of methanolic (a) and aqueous (b) extracts of Ocimum basilicum

Methanolic extracts of selected plants showed absorption band at $2975 \mathrm{~cm}-1$ region due to asymmetric $\mathrm{C}-\mathrm{H}$ stretching of $\mathrm{CH} 3$ of alkane group and at around $2927 \mathrm{~cm}-1$ region due to asymmetric $\mathrm{C}-\mathrm{H}$ stretching of $\mathrm{CH} 2$ of alkane group. The band at $2898 \mathrm{~cm}-1$ is assigned due to the symmetric $\mathrm{C}-\mathrm{H}$ stretching in $\mathrm{CH} 2$ of the alkane group (Fig. 4).

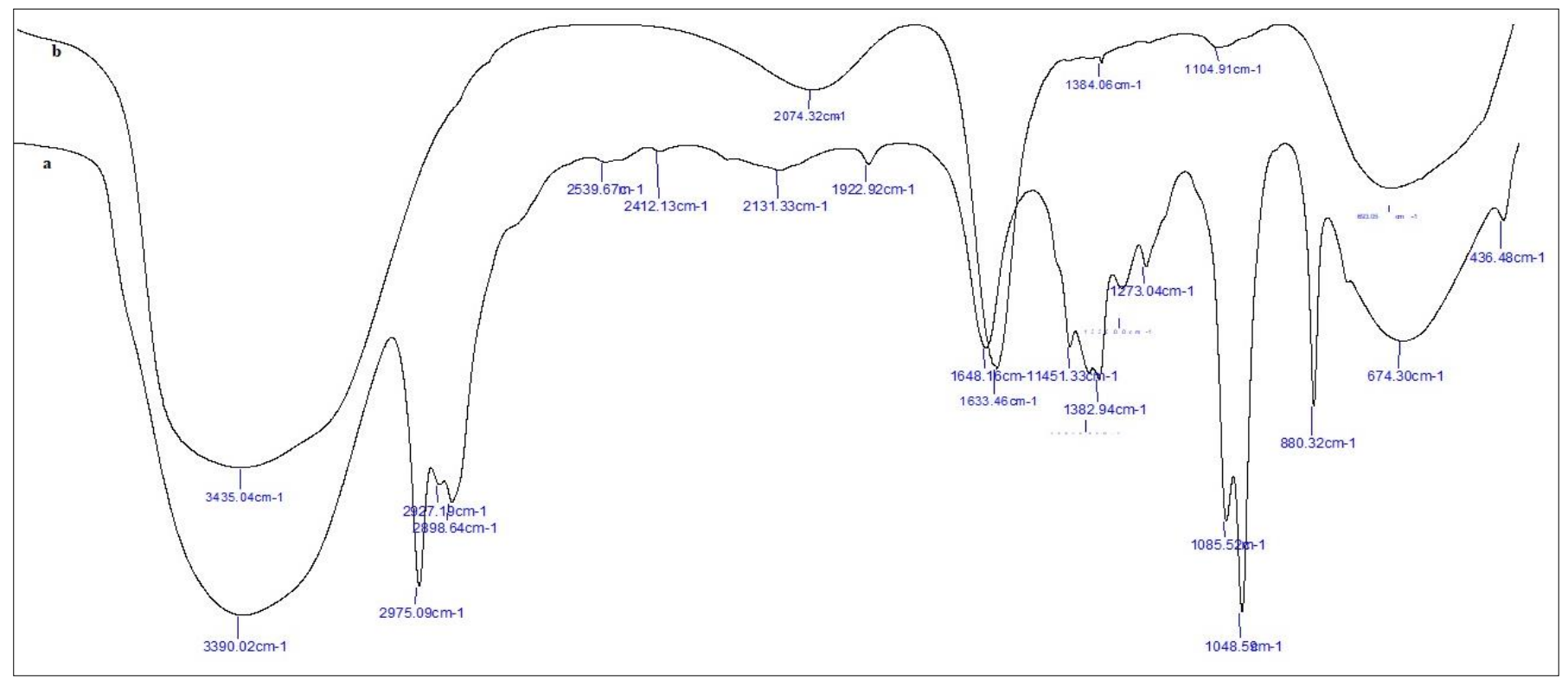

Fig 4: FTIR spectra of methanolic (a) and aqueous (b) extracts of Leucas aspera

Methanolic extract of Ocimum sanctum have a very weak and extended band at $2125 \mathrm{~cm}-1 \mathrm{C}$ of alkynes. The relatively stronger band around $1100 \mathrm{~cm}-1$ and $1120 \mathrm{~cm}-1$ is assigned as $\mathrm{C}-\mathrm{O}$ stretching vibration of primary and secondary alcohols. A notable absorption peak at $878 \mathrm{~cm}-1$ seen in methanoilc extract of $C$. amboinicus is probably due to the bending vibrational mode of $\mathrm{O}-\mathrm{N}-\mathrm{O}$ of the $\mathrm{NO}_{2}$ group confirming the presence of nitro group (Fig. 5). FTIR and EDS spectra of Eclipta alba and Eclipta prostrate described the presence of characteristic functional groups of carboxylic acids, amines, amides, sulphur derivatives, polysaccharides, nitrates, chlorates, and carbohydrate which are responsible for its biological properties ${ }^{[7]}$. 


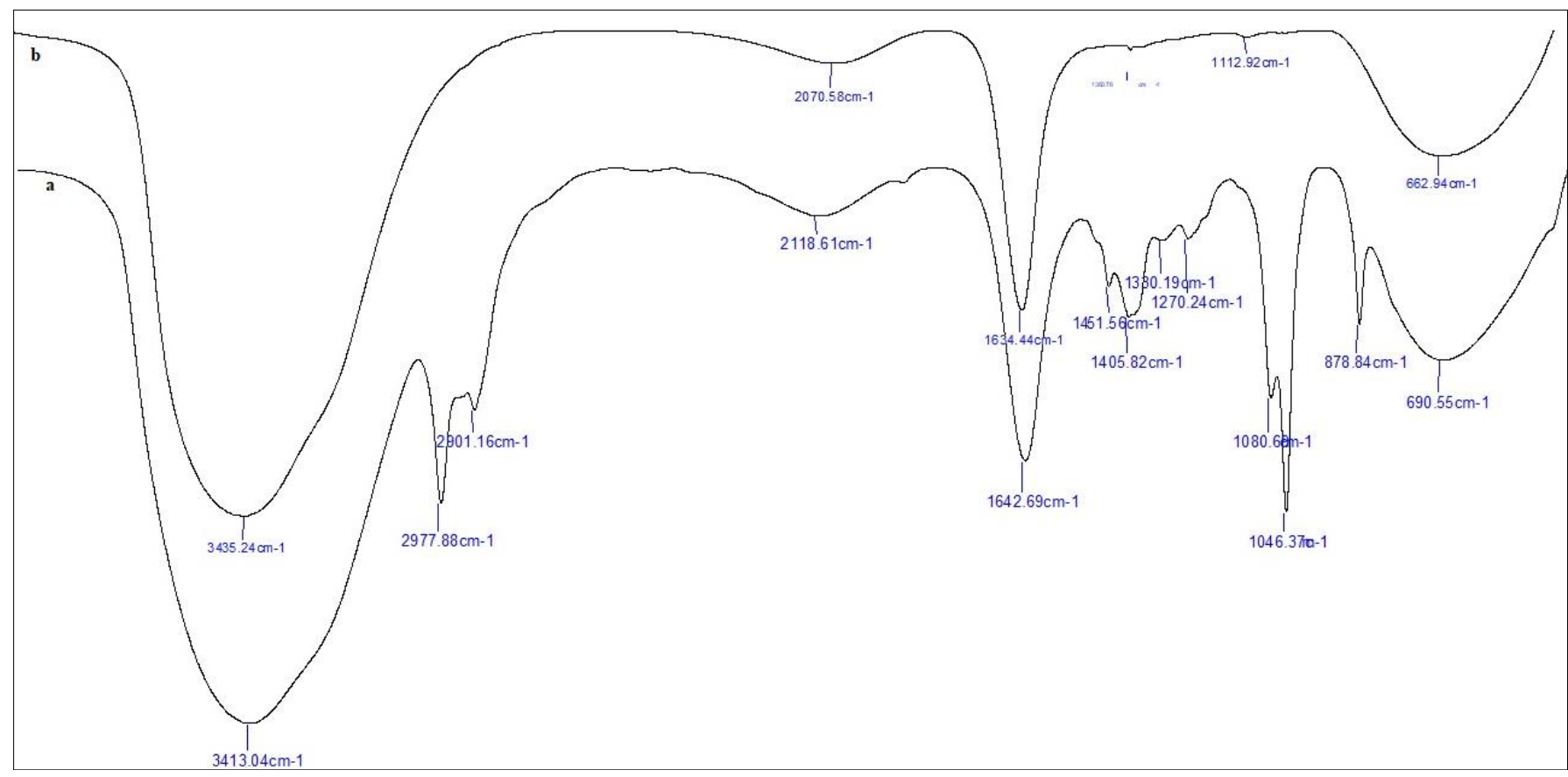

Fig 5: FTIR spectra of methanolic (a) and aqueous (b) extracts of Coleus amboinicus

\subsection{Larvicidal activity}

With respective to the larvicidal activity of the crude plant extracts analyzed, it was observed that after 24 and $48 \mathrm{~h}$ of exposure, both aqueous and methanolic extracts demonstrated relevant results against $\mathrm{L}_{3}$ A. subpictus larvae. Among the selected plants, aqueous extract of Ocimum basilicum $\left(\mathrm{LC}_{50^{-}}\right.$ $0.603 \mu \mathrm{g} / \mathrm{ml}$ ) showed highest lethality at low concentration followed by Leucas aspera ( $\left.\mathrm{LC}_{50} 0.661 \mu \mathrm{g} / \mathrm{ml}\right)$, Coleus amboinicus $\left(\mathrm{LC}_{50} 724.43 \mu \mathrm{g} / \mathrm{ml}\right)$ and Ocimum sanctum $\left(\mathrm{LC}_{50}\right.$ $891.25 \mu \mathrm{g} / \mathrm{ml}$ ) (Table 3).

Table 3: Lethal concentration of aqueous extracts of $O$. sanctum, O. basilicum, L. aspera and C. amboinicus against the larvae in exposure of 24 hours

\begin{tabular}{|c|c|c|c|c|}
\hline Species & LC $_{\mathbf{5 0}}$ & Regression equation & $\mathbf{R}^{\mathbf{2}}$ & $\mathbf{P}$ value $(\mathbf{P}<\mathbf{0 . 0 5})$ \\
\hline Ocimum sanctum & 891.25 & $\mathrm{y}=2.74 \mathrm{x}-3.10$ & 0.93 & 0.007 \\
\hline Ocimumbasilicum & 602.56 & $\mathrm{y}=2.83 \mathrm{x}-2.87$ & 0.89 & 0.016 \\
\hline Leucasaspera & 660.69 & $\mathrm{y}=3.12 \mathrm{x}-3.81$ & 0.95 & 0.044 \\
\hline Coleus amboinicus & 724.43 & $\mathrm{y}=2.90 \mathrm{x}-3.32$ & 0.95 & 0.005 \\
\hline
\end{tabular}

Similarly methanolic extract of Ocimum basilicum was proven to be the most promising control of mosquito larvae which was confirmed by the $\mathrm{LC}_{50} 346.73 \mu \mathrm{g} / \mathrm{ml}$. Comparably methanolic extracts of selected plants showed lethality at low concentrations than aqueous extracts (Ocimum sanctum $\mathrm{LC}_{50} 524.81 \mu \mathrm{g} / \mathrm{ml}$, Leucas aspera - $\mathrm{LC}_{50} 575.44 \mu \mathrm{g} / \mathrm{ml}$, Coleus amboinicus - $\mathrm{LC}_{50} 575.43 \mu \mathrm{g} / \mathrm{ml}$ ) values obtained after $24 \mathrm{~h}$ of exposure (Table 4). The toxic effect of Ocimum Sanctum extract against the early fourth instar larvae of Aedes aegypti was least and this is in par with the work done by
Senthilnathan et al. ${ }^{[20]}$ where combination of all plant extract were tested against fourth instar larvae of culex quinquefasciatus. Sakthivadivel and Daniel ${ }^{[21]}$ observed that petroleum ether extract of Leucas aspera with $\mathrm{LC}_{50}$ value between 100 to $200 \mathrm{ppm}$ against the larvae of $C$. quinquefasciatus, A. stephensi and A. aegypti. However use of plant extracts for developing mosquito larvicides and their mode of action was clearly explained by Pavela et al. ${ }^{[22]}$ and Piplani et al. ${ }^{[23]}$

Table 4: Lethal concentration of methanolic extracts of $O$. sanctum, O. basilicum, L. aspera and C.amboinicus against the larvae in exposure of 24 hours

\begin{tabular}{|c|c|c|c|c|}
\hline Species & LC $_{\mathbf{5 0}}$ & Regression equation & $\mathbf{R}^{\mathbf{2}}$ & P value $(\mathbf{P}<\mathbf{0 . 0 5})$ \\
\hline Ocimum sanctum & 524.81 & $\mathrm{y}=2.64 \mathrm{x}-2.17$ & 0.96 & 0.003 \\
\hline Ocimumbasilicum & 346.73 & $\mathrm{y}=2.58 \mathrm{x}-1.56$ & 0.95 & 0.004 \\
\hline Leucasaspera & 575.44 & $\mathrm{y}=2.54 \mathrm{x}-2.01$ & 0.85 & 0.025 \\
\hline Coleus amboinicus & 575.43 & $\mathrm{y}=2.30 \mathrm{x}-1.35$ & 0.90 & 0.0013 \\
\hline
\end{tabular}

Aqueous extracts of selected plants showed varying levels of mortality (Table 5) whereas no dead larva was observed in control even after 24 hours of exposure. Among the species tested, Ocimum basilicum recorded highest mortality rate (85\%) following Leucas aspera (80\%), Coleus amboinicus
(72\%) and Ocimum sanctum (60\%) respectively (Fig. 6). Larvicidal activity of Ocimum sanctum L. was reported very earlier by Keirn and Nair ${ }^{[24]}$. Essential oil of Ocimum sanctum L. revealed larvicidal efficacy against larvae of $A$. stephensi, A. aegypti and C. quinquefasciatus ${ }^{[25]}$.

Table 5: Mean Mortality Rate of aqueous extracts of selected plants against $A$. subpictus after 24 hours exposure 


\begin{tabular}{|c|c|c|c|c|c|c|c|c|c|c|c|c|}
\hline \multirow[b]{2}{*}{$\begin{array}{c}\text { Conc } \\
(\mu \mathrm{g} / \mathrm{ml})\end{array}$} & \multicolumn{3}{|c|}{$\begin{array}{c}\text { Aqueous extract of } \\
\text { O. sanctum }\end{array}$} & \multicolumn{3}{|c|}{$\begin{array}{c}\text { Aqueous extract of } \\
\text { O. basilicum }\end{array}$} & \multicolumn{3}{|c|}{$\begin{array}{c}\text { Aqueous extract of } \\
\text { L. aspera }\end{array}$} & \multicolumn{3}{|c|}{$\begin{array}{c}\text { Aqueous extract of } \\
\text { C. amboinicus }\end{array}$} \\
\hline & $\begin{array}{c}\% \text { Dead } \\
\text { larvae } \pm \\
\mathrm{SE}\end{array}$ & $\begin{array}{c}\text { Probit } \\
\text { mortality }\end{array}$ & $\begin{array}{l}\text { \% Alive } \\
\text { larvae }\end{array}$ & $\begin{array}{c}\% \text { Dead } \\
\text { larvae } \pm \\
\mathrm{SE}\end{array}$ & $\begin{array}{c}\text { Probit } \\
\text { mortality }\end{array}$ & $\begin{array}{l}\% \text { Alive } \\
\text { larvae }\end{array}$ & $\begin{array}{c}\% \text { Dead } \\
\text { larvae } \pm \\
\mathrm{SE}\end{array}$ & $\begin{array}{c}\text { Probit } \\
\text { mortality }\end{array}$ & $\begin{array}{l}\text { \% Alive } \\
\text { larvae }\end{array}$ & $\begin{array}{c}\% \text { Dead } \\
\text { larvae } \pm \\
\mathrm{SE}\end{array}$ & $\begin{array}{c}\text { Probit } \\
\text { mortality }\end{array}$ & $\begin{array}{l}\% \text { Alive } \\
\text { larvae }\end{array}$ \\
\hline 0.2 & $5 \pm 0.04$ & 3.36 & 95 & $12 \pm 0.04$ & 3.82 & 88 & $7 \pm 0.02$ & 3.52 & 93 & $7 \pm 0.02$ & 3.52 & 93 \\
\hline 0.4 & $13 \pm 0.05$ & 3.87 & 87 & $28 \pm 0.10$ & 4.42 & 72 & $20 \pm 0.07$ & 4.16 & 80 & $17 \pm 0.06$ & 4.05 & 83 \\
\hline 0.6 & $22 \pm 0.08$ & 4.23 & 78 & $40 \pm 0.14$ & 4.75 & 60 & $42 \pm 0.15$ & 4.80 & 58 & $32 \pm 0.11$ & 4.53 & 68 \\
\hline 0.8 & $50 \pm 0.18$ & 5 & 50 & $56 \pm 0.20$ & 5.15 & 44 & $53 \pm 0.19$ & 5.08 & 47 & $55 \pm 0.21$ & 5.13 & 45 \\
\hline 1.0 & $60 \pm 0.22$ & 5.25 & 40 & $85 \pm 0.31$ & 6.04 & 15 & $80 \pm 0.29$ & 5.84 & 20 & $72 \pm 0.26$ & 5.58 & 28 \\
\hline
\end{tabular}

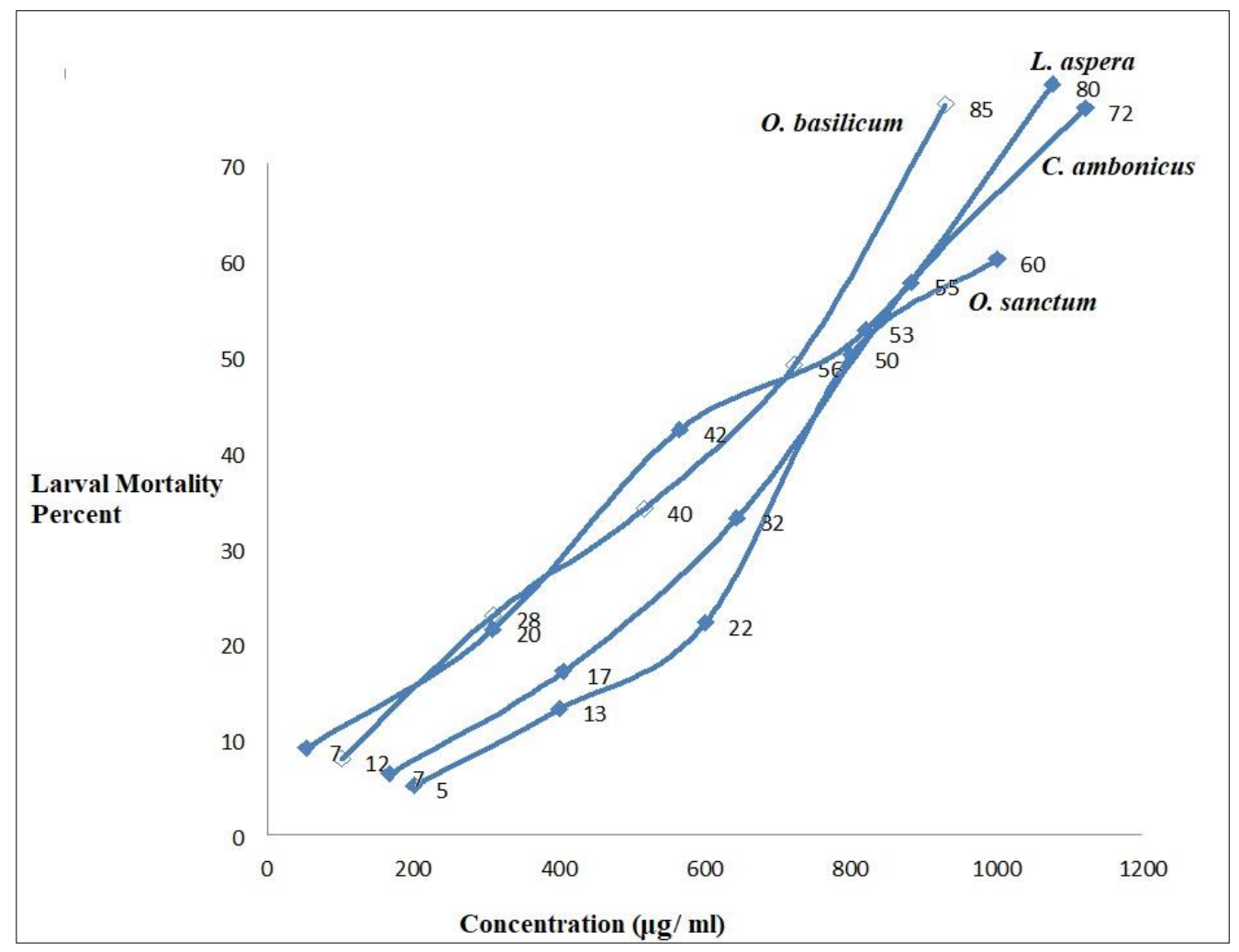

Fig 6: Mortality rate of aqueous extracts of $O$. sanctum, O. basilicum, L. aspera and C. amboinicus after 24 hours exposure

As well methanolic extracts showed varying mortality rates at different concentrations of the extracts tested (Table 6). No dead larva was observed in control even after 24 hours of exposure. After 24 hours of exposure, mortality rates tend to increase in response to increasing concentrations. Among the selected plants, Ocimum basilicum recorded highest mortality rate (92\%) following Leucas aspera (83\%), Ocimum sanctum (82\%) and Coleus amboinicus (80\%) respectively (Fig. 7). It is obvious that methanolic extract of $L$. aspera and $O$. sanctum exhibited approximately same mortality rates against A. subpictus. In general mortality rate of methanolic extract was higher when compared to the mortality rates exhibited by aqueous extracts. However, there was significant difference ( $P$ $<0.05)$ in the mortality rate of Anopheles species larvae between extracts of all for each concentration degree of freedom-1 for each extracts. Larvidal activity of $O$. basilicum, Thymus vulgaris, Cymbopogan citatus, Mentha arvensis and $P$. graveolens essential oils were reported against the late third instar of $C$. quinquefasciatus. The $\mathrm{LC}_{50}$ values of $O$. basilicum, T. vulgaris, C. citatus, $M$. arvensis and $P$. graveolens were 29.98, 30.31, 165.70, 178.04 and 226.52 ppm respectively ${ }^{[26]}$. Recently Dris et al. ${ }^{[27]}$ tested $O$. basilicum leaf extracts against fourth instar $C$. pipiens $\mathrm{L}$. larvae and informed $\mathrm{LC}_{50}$ value of $73.45 \mathrm{ppm}$. Additionally larvicidal activity of medicinal plant extracts (Annona squamosa, Chrysanthemum indicum and Tridax procumbens) against fourth instar larvae of Anopheles subpictus and Culex tritaeniorhynchus was reported by Kamaraj et al. ${ }^{[28]}$ 
Table 6: Mean Mortality Rate of methanolic extracts of selected plants against A. subpictus after 24 hours exposure

\begin{tabular}{|c|c|c|c|c|c|c|c|c|c|c|c|c|}
\hline \multirow[b]{2}{*}{$\begin{array}{c}\text { Conc } \\
(\mu \mathrm{g} / \mathrm{ml})\end{array}$} & \multicolumn{3}{|c|}{$\begin{array}{c}\text { Methanolic extract of } \\
\text { O. sanctum }\end{array}$} & \multicolumn{3}{|c|}{$\begin{array}{c}\text { Methanolic extract of } \\
\text { O. basilicum }\end{array}$} & \multicolumn{3}{|c|}{$\begin{array}{c}\text { Methanolic extract of } \\
\text { L. aspera }\end{array}$} & \multicolumn{3}{|c|}{$\begin{array}{c}\text { Methanolic extract of } \\
\text { C. amboinicus }\end{array}$} \\
\hline & $\begin{array}{c}\% \text { Dead } \\
\text { larvae } \pm \\
\text { SE }\end{array}$ & $\begin{array}{c}\text { Probit } \\
\text { mortality }\end{array}$ & $\begin{array}{l}\text { \% Alive } \\
\text { larvae }\end{array}$ & $\begin{array}{c}\% \text { Dead } \\
\text { larvae } \pm \\
\mathrm{SE}\end{array}$ & $\begin{array}{c}\text { Probit } \\
\text { mortality }\end{array}$ & $\begin{array}{l}\text { \% Alive } \\
\text { larvae }\end{array}$ & $\begin{array}{c}\% \text { Dead } \\
\text { larvae } \pm \\
\mathrm{SE}\end{array}$ & $\begin{array}{c}\text { Probit } \\
\text { mortality }\end{array}$ & $\begin{array}{l}\text { \% Alive } \\
\text { larvae }\end{array}$ & $\begin{array}{c}\% \text { Dead } \\
\text { larvae } \pm \\
\text { SE }\end{array}$ & $\begin{array}{c}\text { Probit } \\
\text { mortality }\end{array}$ & $\begin{array}{l}\text { \% Alive } \\
\text { larvae }\end{array}$ \\
\hline 0.2 & $17 \pm 0.06$ & 4.05 & 83 & $32 \pm 0.11$ & 4.53 & 68 & $18 \pm 0.07$ & 4.08 & 82 & $18 \pm 0.06$ & 4.08 & 82 \\
\hline 0.4 & $33 \pm 0.12$ & 4.56 & 67 & $52 \pm 0.19$ & 5.05 & 48 & $27 \pm 0.09$ & 4.39 & 73 & $32 \pm 0.11$ & 4.53 & 68 \\
\hline 0.6 & $52 \pm 0.19$ & 5.05 & 48 & $68 \pm 0.25$ & 5.47 & 32 & $38 \pm 0.14$ & 4.69 & 62 & $43 \pm 0.15$ & 4.82 & 57 \\
\hline 0.8 & $70 \pm 0.25$ & 5.52 & 30 & $82 \pm 0.29$ & 5.92 & 18 & $65 \pm 0.23$ & 5.39 & 35 & $58 \pm 0.21$ & 5.20 & 42 \\
\hline 1.0 & $82 \pm 0.30$ & 5.92 & 18 & $92 \pm 0.33$ & 6.14 & 8 & $83 \pm 0.30$ & 5.95 & 17 & $80 \pm 0.29$ & 5.84 & 20 \\
\hline
\end{tabular}

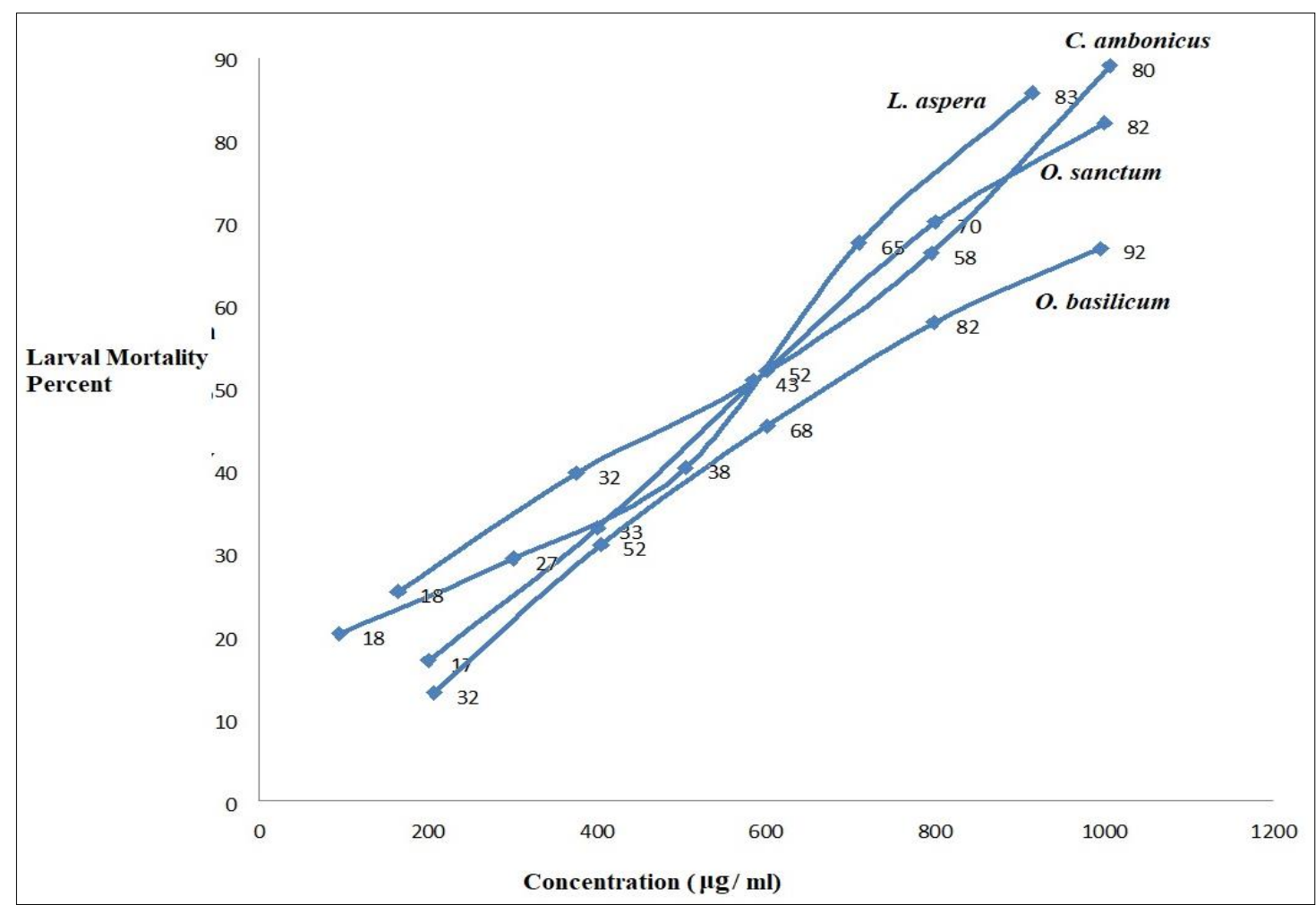

Fig 7: Mortality rate of methanolic extracts of O. sanctum, O. basilicum, L. aspera and C. amboinicus after 24 hours exposure

In the present study first and second instar larvae were extremely profound when compared with third and fourth instar larvae of both the test species. The present findings support the results of Muthukrishan et al. ${ }^{[29]}$ as they observed the $\mathrm{LC}_{50}$ values of ethyl acetate extract of $L$. aspera were $75.40,93.09,132.20$ and 138.60 against the first, second, third and fourth instar larvae of $C$. quinquefasciatus, respectively. Mwangi and Rembold ${ }^{[30]}$ reported that the leaf extract of $L$. aspera exhibited high mortality, especially during the molting process or the successive processes of melanization and tanning. Murugam and Jayabalan [31] observed 90\% larval mortality at $4 \%$ concentration of leaf extracts of $L$. aspera against fourth instar larvae (Anopheles stephensi).

Carvacrol was also found to be the main essential of Thymus herbabarona essential oil and showed to be toxic to the Lepidopteran larvae Limantria dispar ${ }^{[32]}$. The in vitro antimalarial action of $C$. dactylon and other therapeutic plant extracts was detected to be important against Plasmodium falciparum ${ }^{[33]}$. In my observation O.sanctum, O.basilicum, L,aspera, C. amboinicus showed various phytochemicals and functional groups and the larvicidal activity of $O$. basilicum and $L$. aspera were exposed highest larvicidal activity against to Anopheles species rather than, $O$. sanctum and $C$. amboinicus
These tests indicated that lower concentrations are needed for the plant extracts to obtain a larval mortality of $90 \%$ of the population that can be used as larvicides to control mosquito. Over the past three decades plant products have drawn attention as potent insect control agents aiming only larval stages in the mosquito control programme.

\section{Conclusion}

Results obtained from this study have initiated on-going investigations into the incorporation of these crude plant extracts into the control of mosquito populations, with a view for developing an environmentally acceptable product of value in integrated vector control. The use of a plant extract that reduce mosquito populations at the larval stage can provide many associated benefits to vector control.

\section{Acknowledgement}

The authors thank the authorities of St. Joseph's College, Tiruchirappalli for providing facilities to conduct the experiments.

\section{References}

1. Nicoletti M. Insect-Borne Diseases in the 21st Century: 
Three scenarios in insect-borne diseases 2020, 99-251.

2. Walker K, Lynch M. Contributions of Anopheles larval control to malaria suppression in tropical Africa: review of achievements and potential. Med Vet Entomol 2007;21(1):2-21.

3. WHO. Dengue: guidelines for diagnosis. Treatment, prevention and control. In: World Health Organization (ed). World Health Organization, Geneva 2009.

4. Alshebly MM, Alqahtani FS, Govindarajan M, Gopinath K, Vijayan P, Benelli G. Toxicity of ar-curcumene and epi- $\beta$-bisabolol from Hedychium larsenii (Zingiberaceae) essential oil on malaria, chikungunya and St. Louis encephalitis mosquito vectors. Ecotoxicol. Environ. Safe 2017;137:149-157

5. Naucke TJ, Kropke R, Benner G, Schulz J, Wittern KP, Rose A, et al. Field evaluation of the efficacy of proprietary repellent formulations with IR3535 and picaridin against Aedes aegypti. Parasitol Res 2007;101(1):169-177.

6. Mukandiwa L, Eloff JN, Naidoo V. Larvicidal activity of leaf extracts and seselin from Clausena anisata (Rutaceae) against Aedes aegypti. South African J Bot 2015;100:169-173.

7. Elango G, Bagavan A, Kamaraj C, Abdul AZ, Abdul Rahuman. Oviposition-deterrent, ovicidal, and repellent activities of indigenous plant extracts against Anopheles subpictus Grassi (Diptera: Culicidae). Parasitol. Res 2009;105(6):1567-76.

8. Govindarajan M, Sivakumar RM, Rajeswari M, Yogalakshmi K. Chemical composition and larvicidal activity of essential oil from Ocimum basilicum (L.) against Culex tritaeniorhynchus, Aedes albopictus and Anopheles subpictus (Diptera: Culicidae). Exp. Parasitol 2013;134(1):7-11.

9. Asadollahi A, Khoobdel M, Alireza ZR, Azarmi S, Hussain S, Mosawi. Effectiveness of plant-based repellents against different Anopheles species: a systematic review. Malaria J 2019;18:436.

10. Shaalan EAS, Canyonb D, Younesc MWF, Abdelwahaba $\mathrm{H}$, Mansoura AH. A review of botanical phytochemicals with mosquitocidal potential. Environ Int 2005;3:1149-66.

11. Trease GE, Evans WC. Pharmacognosy (13th edn). Bailliere Tindall, London 1989, 176-180.

12. Sofowora LA. Medicinal plants and traditional medicine in Africa spectrum books Ltd, Ibadan 1993, 55-71.

13. World Health Organization. Guidelines for Laboratory and Field Testing of Mosquito Larvicides, WHO Geneva. 2005.

14. Abbott WS. A method for computing the effectiveness of an insecticide. J Econ Entomol 1975;18:265-267.

15. Finney DJ. Probit analysis. $3^{\text {rd }}$ Edition Cambridge University Press, Cambridge 1971.

16. Ghosh A, Chowdhury N, Chandra G. Plant extracts as potential mosquito larvicides. Indian $\mathrm{J}$ Med Res 2012;135(5):581-98.

17. Sattar A. In: Proceeding of the First National Symposium on Essential Oil, Perfumes and Flavour, PCSIR Laboratories Complex, Lahore 1989, 7-12.

18. Bansal T, Kaur H. Benefits of essential oil. J Chem Pharma Res 2016;8(6):143-149.

19. Raina AP, Kumar A, Dutta M. Chemical characterization of aroma compounds in essential oil isolated from "Holy
Basil", (Ocimum tenuiflorum L.) grown in India. Genet. Res. Crop Evol 2013;60:1727-1735.

20. Senthilnathan S, Savitha G, George DK, Narmadha A, Suganya L, Chung PG. Efficacy of Melia azadirach L. extract on the malarial vector Anopheles stephensi liston (Diptera: Culicidae). Biores. technol 2006;97:1316-1323.

21. Sakthivadivel M, Daniel T. Evaluation of certain insecticidal plants for the control of vector mosquitoes viz., Culex quinquefasciatus, Anopheles stephensi and Aedes aegypti. Appl. Entomol. Zool 2008;43(1):57-63.

22. Pavela R, Maggi F, Iannarelli R, Benelli G. Plant extracts for developing mosquito larvicides: From laboratory to the field, with insights on the modes of action. Acta Trop 2019;193:236-271.

23. Piplani M, Bhagwat DP, Singhvi G, Sankaranarayanan M, Balana-fouce R, Vats T, et al. Plant-based larvicidal agents: An overview from 2000 to 2018. Exp Parasitol 2019;199:92-103.

24. Keirn MA, Nair MG. Mosquitocidal compounds and triglyceride, 1,3- dilinolenoeol-2- palmitin from Ocimum sanctum. J Agric. Food Chem 1998;40:3691-3693.

25. Vinayagam A, Senthilkumar N, Umamaheswari A. Larvicidal activity of some medicinal plant extracts against malaria vector Anopheles stephensi. Res J Parasitol 2008;3:50-58.

26. Pushpanathan T, Jebanesan A, Govindarajan M Larvicidal efficacy of certain plant essential oils against Culex quinquefasciatus (Diptera: Culicidae). J. Exp. Zool. India 2008c;11(1):159-160.

27. Dris D, Tine-Djebbar F, Bouabida H, Soltani N. Chemical composition and activity of an Ocimum basilicum essential oil on Culex pipiens larvae: Toxicological, biometrical and biochemical aspects. South African J Bot 2017;113:362-369.

28. Kamaraj C, Abdul Rahman A, Bagavan A, Abduz Zahir A, Elango G, Kandan P, et al. Larvicidal efficacy of medicinal plant extracts against Anopheles stephensi and Culex quinquefasciatus (Diptera: Culicidae). Trop Biomed 2010;27(2):211-9.

29. Muthukrishnan J, Pushpalatha H, Kasthuribhai K. Biological effects of four plant extracts on Culex quinquefasciatus Say. larval stages. Insect Sci. Appl 1997; 17(3/4):389-394.

30. Mwangi RW, Rembold H. Growth inhibiting and larvicidal effects of Melia volkensii extracts on Aedes aegypti larvae. Entomol Exp Appl 1988;46:103-108.

31. Murugan K, Jayabalan D. Effect of certain plant extracts the mosquito, Anopheles stephensi Liston. Current Sci 1999;76(5):631-633.

32. Moretti MDL, Sanna-Passino G, Demontis S. et al. Essential oil formulations useful as a new tool for insect pest control. AAPS Pharm. Sci. Tech 2002;3:64-74.

33. Bagavan A, Abdul Rahuman A, Kamaraj C, Kaushik NK, Mohanakrishnan D, Sahal D. Antiplasmodial activity of botanical extracts against Plasmodium falciparum. Parasitol Res 2011;108:1099-1109. 